\title{
Metabolizable protein systems in ruminant nutrition: A review
}

\author{
Lalatendu Keshary Das ${ }^{1}$, S. S. Kundu², Dinesh Kumar ${ }^{3}$ and Chander Datt ${ }^{2}$
}

1. Veterinary Dispensary, Kalampur, Kalahandi, Odisha, India; 2. Division of Dairy Cattle Nutrition, National Dairy Research Institute, Karnal, Haryana, India; 3. Division of Animal Nutrition, Indian Veterinary Research Institute, Izatnagar, Uttar Pradesh, India.

Corresponding author: Lalatendu Keshary Das, email: drlalatendu27@gmail.com

SSK: sskundu.kIn@gmail.com, DK: kr.dinesh7@gmail.com,CD: chandatt@gmail.com

Received: 15-05-2014, Revised: 07-07-2014, Accepted: 15-07-2014, Published online: 27-08-2014

doi: 10.14202/vetworld.2014.622-629. How to cite this article: Das LK, Kundu SS, Kumar D, Datt C (2014) Metabolizable protein systems in ruminant nutrition: A review. Veterinary World 7(8): 622-629.

\begin{abstract}
Protein available to ruminants is supplied by both microbial and dietary sources. Metabolizable protein (MP) is the true protein which is absorbed by the intestine and supplied by both microbial protein and protein which escapes degradation in the rumen; the protein which is available to the animal for maintenance, growth, fetal growth during gestation, and milk production. Thus, the concept of balancing ruminant rations basing on only dietary crude protein (CP) content seems erroneous. In India, ruminant rations are still balanced for digestible CP and total digestible nutrients for protein and energy requirements, respectively. Traditional feed analysis methods such as proximate analysis and detergent analysis consider feed protein as a single unit and do not take into account of the degradation processes that occur in rumen and passage rates of feed fractions from rumen to intestine. Therefore, the protein requirement of ruminants should include not only the dietary protein source, but also the microbial CP from rumen. The MP systems consider both the factors, thus predict the protein availability more accurately and precisely. This system is aptly designed to represent the extent of protein degradation in the rumen and the synthesis of microbial protein as variable functions. Feed protein fractions, i.e., rumen degradable protein and rumen undegradable protein play vital roles in meeting protein requirements of rumen microbes and host animal, respectively. With the advent of sophisticated nutrition models such as Cornell net carbohydrate and protein system, National Research Council, Agricultural Research Council, Cornell Penn Miner Dairy and Amino Cow; ration formulation has moved from balancing diets from CP to MP, a concept that describes the protein requirements of ruminants at intestinal level, and which is available to animals for useful purposes.
\end{abstract}

Keywords: digestible crude protein, metabolizable protein, microbial protein, protein requirement, total digestible nutrients.

\section{I ntroduction}

The shortage of feeds and forages is the major constraint in accelerating the growth of animal production in India [1,2]. The feeding stuffs available are of poor quality and their nutrients are poorly utilized by animals. These feedstuffs are less digestible and contain lower quantities of energy, protein, minerals, and vitamins; consequently, the nutrients available to animals are further decreased. Crude protein (CP) content of these feedstuffs is low, and its utilization is further impeded due to non-availability of rumen fermentable energy source. In ruminants, a large portion of the feed protein is transformed into microbial protein and is ultimately absorbed along with escaped feed protein. Absorbable amino acids from feed origin and microbial origin constitute metabolizable protein (MP), which is in true sense utilized by the animal for maintenance, growth, and production $[3,4]$.

For many years, CP content has been used in formulating diets for lactating dairy cows because there was little information available regarding the response of dietary protein in complex ruminal microbial environment [5]. In addition, it was long been postulated that the high quality microbial crude protein (MCP)

Copyright: The authors. This article is an open access article licensed under the terms of the Creative Commons Attributin License (http:// creative commons.org/licenses/by/2.0) which permits unrestricted use, distribution and reproduction in any medium, provided the work is properly cited. synthesized in the rumen would complement deficiencies in the quality of dietary protein that escaped ruminal fermentation. However, for high yielding cows, microbial protein synthesis supplies a decreasing proportion of the required protein, and significant amounts of dietary protein must escape ruminal degradation in order to meet protein needs. On the other hand, the animal scientists are under strong pressure to design ways to reduce nitrogen $(\mathrm{N})$ losses from ruminants in order to prevent environmental pollution. Therefore, present research works are being diverted toward improving the efficiency of $\mathrm{N}$ utilization by lactating cows while maintaining optimum milk production levels. The CP system does not have a provision for differentiating between the requirements of ruminal microbes and the requirements of the host animal. Therefore, supplementations based on the CP system may result in protein deficiencies in animal. Thus, time has come to replace the current protein evaluation system to MP system, which has many advantages over the old ones. The system provides a more rational description of the energy available for microbial growth (fermentable metabolizable energy [FME]) by discounting the energy content of dietary lipids and fermentation end products [6]. Another advantage with MP system is that it provides a framework with which the net absorption of amino acids from the small intestine can be computed in relation 
to the animal's requirement [7]. MP system is also a better predictor of milk yield in lactating animals than CP [8]. Hence, replacement of conventional CP system with MP system seems to be a better idea to define and refine protein utilization and diet formulation as this system fits well with the biology of ruminants [9].

\section{Concept of MP}

There are three basic goals in protein nutrition in ruminants. First, to meet the rumen degradable protein (RDP) requirements of rumen microbes (ammonia, amino acids, and peptides) for maximum carbohydrate digestion and microbial protein synthesis. Second, to meet the MP requirements (MPRs) of host animal for maintenance, growth, optimum health, and reproduction with minimal intake of rumen undegradable protein (RUP) and finally, to meet the MP and amino acids requirements of a cow for a desired milk yield having a desired level of protein and fat with minimum dietary $\mathrm{CP}$. The initial concept of MP systems was proposed by Burroughs et al. [10] in USA, which was further modified by nutrition models of Agricultural Research Council (ARC) [11] and National Research Council (NRC) [12]. However, the system is fully described in the 1992 Report of the Agricultural and Food Research Council's Technical Committee on Responses to Nutrients [13], which is popularly known as UK MP system. A similar system called true protein digested in the small intestine (PDI) was developed in France, and the Dutch MP system (DVE/OEB system) was developed in The Netherland. The fundamental principle underlying all these systems is that the protein requirements of a ruminant are most logically considered in two parts: A requirement for protein by rumen microbes and a requirement by host ruminant animal. Ruminal degradation pattern of feed carbohydrate and protein fractions plays a major role in deciding the availability of $\mathrm{N}$ and energy for microbial growth. Availability of $\mathrm{N}$ sources must be synchronized with availability of energy for efficient microbial growth and optimum microbial protein synthesis, otherwise there is wastage of $\mathrm{N}$ in the form of ammonia excretion and ultimately it results in environmental pollution [14]. The nutritive value of MP for dairy cows is determined by its profile of essential amino acids, particularly that of lysine and methionine [15]. Improving the efficiency of protein and $\mathrm{N}$ usage while striving for optimal productivity is a matter of practical concern. Research studies [16-18] have shown that milk protein content and yield can be increased by improving the profile of amino acids in MP, by reducing the amount of surplus protein in the diet, and by increasing the amount of fermentable carbohydrate in the diet.

\section{MPR}

As discussed earlier, the requirements of MP are met from two sources, i.e. ,digestible microbial protein and undegraded dietary protein in ruminants. NRC [9] adopted a factorial approach in estimating the MPRs in dairy cattle. The net protein requirements include that needed for maintenance and production. The maintenance requirement consists of urinary endogenous N, scurf N (skin, skin secretions and hair), and metabolic fecal $\mathrm{N}$. The requirement for production includes the protein needed for conception, growth, and lactation, etc. Three primary differences existed between NRC [9] and NRC [12] in regard to calculate MPRs. First, new equations were introduced for predicting MPRs for endogenous urinary protein, scurf protein, metabolic fecal protein, growth, and pregnancy. Second, the efficiency of conversion of MP to milk protein was changed from $70 \%$ to $67 \%$ and finally, an MPR for endogenous MP was introduced. In view of a lack of published data, the efficiency of use of absorbed MP for endogenous MP was assumed to be $67 \%$.

MPRs for maintenance for growing cattle were estimated as $3.8 \mathrm{~g} / \mathrm{d} / \mathrm{kg}$ metabolic body weight (BW) $\left(\mathrm{kg}^{0.75}\right)$ and for growth as $305 \mathrm{~g} / \mathrm{kg}$ live wt. gain using weighted regression analysis [19]. The MPRs for a $253 \mathrm{~kg}$ steer gaining $0.49 \mathrm{~kg} / \mathrm{d}$ and consuming $3.18 \mathrm{~kg} / \mathrm{d}$ total digestible nutrients (TDN) were calculated to be $390 \mathrm{~g} / \mathrm{d}$. NRC [12], Burroughs et al. [10] and ARC [11] gave MPRs for the same animal to be 498, 275, and $362 \mathrm{~g} / \mathrm{d}$, respectively. The French MP system $[20,21]$ calculated the maintenance requirements of $3.25 \mathrm{~g} / \mathrm{d} / \mathrm{kg}$ metabolic BW $\left(\mathrm{kg}^{0.75}\right)$. Burroughs et al. [10] adopted an efficiency of $47 \%$ for converting MP to net protein. This efficiency is calculated to be $67 \%$ as per ARC [11]; NRC [12] and NRC [9]. Dietary CP content of $13.5 \%$ and MP content of $7.94 \%$ were found to be sufficient for growing Sahiwal calves for daily BW gain of around $0.75 \mathrm{~kg} / \mathrm{d}$ [22].

MPRs for maintenance in Nellore heifers, bulls and steers averaging 16 months of age were evaluated [23]. The net protein requirement was calculated as $2.69 \mathrm{~g} / \mathrm{kg} \mathrm{BW}^{0.75}$ irrespective of sexual categories. The MPR for maintenance of Nellore cattle was estimated as $4.0 \mathrm{~g} / \mathrm{kg} \mathrm{BW}{ }^{0.75}$. NRC [3] recommended MPR for maintenance as $3.8 \mathrm{~g} / \mathrm{kg} \mathrm{BW}^{0.75}$ in zebu cattle. Ezekiel [24] obtained MPRs for maintenance of 1.72 and $4.28 \mathrm{~g} / \mathrm{kg} \mathrm{BW}^{0.75} / \mathrm{d}$ for Nellore and Holstein, respectively. Valadares [25] calculated MPR for maintenance of $4.13 \mathrm{~g} / \mathrm{kg} \mathrm{BW}^{0.75} / \mathrm{d}$ in zebu cattle. Hill [26] estimated the value of $1.63 \mathrm{~g} / \mathrm{kg} \mathrm{BW}^{0.75} / \mathrm{d}$ in Nellore. Vermeulen [27] estimated MPRs of beef cows (avg. BW $499 \mathrm{~kg}$ ) with a peak milk yield of $6.4 \mathrm{~kg} / \mathrm{d}$ to be $734 \mathrm{~g} / \mathrm{d}$ as per NRC [3].

Luo et al. $[28,29]$ predicted MPRs for maintenance, gain and fiber growth of growing, and mature Angora goats using multiple regression analysis. The MPR for maintenance was $3.35 \mathrm{~g} / \mathrm{kg} \mathrm{BW}{ }^{0.75}$. The MPRs for maintenance for all biotypes of growing goats were obtained as $3.07 \mathrm{~g} / \mathrm{kg} \mathrm{BW}^{0.75}$ by regressing MPI (MP intake) against average daily gain (ADG). The MPRs for BW gain of meat goats were predicted to be $0.404 \mathrm{~g} / \mathrm{g}$ of ADG and for dairy and indigenous goats, the requirement was $0.290 \mathrm{~g} / \mathrm{g}$ of ADG. 
Similarly, the MPRs for Santa Ines and wool lambs, with $20 \mathrm{~kg}$ initial BW and an approximate $200 \mathrm{~g}$ mean daily wt. gain were 59.4 and $76.5 \mathrm{~g} / \mathrm{d}$ as per Silva et al. [30].

\section{MP availability from feeds or feed combinations}

Knowledge of CP and total carbohydrate content of the feed, CP, and carbohydrate intake, fractional degradation rate of different feed fractions, passage rates of feed fractions, RDP and RUP values of feed, microbial protein synthesis, etc., are the major inputs in calculating the availability of MP from a feed or total mixed ration (TMR) in Cornell net carbohydrate and protein (CNCP) system [31]. NRC [9] considers TDN value of a feed in estimating the MP availability, while AFRC [13] considers the FME content of the feed in calculation of MP value of that feed.

Blouin et al. [32] assessed the availability of MP in dairy cows from two isoenergetic (1.62 Mcal NE/kg $\mathrm{DM})$ and isonitrogenous $(16.3 \% \mathrm{CP})$ diets. These two diets supplied 1930 and $1654 \mathrm{~g} / \mathrm{d}$ of MP due to variation in microbial protein, RDP and RUP supply. In another similar experiment [33], two isonitrogenous and isoenergetic diets $(17.5 \% \mathrm{CP}$ and $1.45 \mathrm{Mcal} / \mathrm{kg}$ $\mathrm{NE}_{\mathrm{L}}$ ) when fed at $26 \mathrm{~kg} / \mathrm{d}$ supplied 2197 and $2674 \mathrm{~g} / \mathrm{d}$ MP, which suggested that there was no direct relationship between CP and MP. Researchers also studied the availability of MP from diets with different level of protein. Raggio et al. [34] estimated the MP availability from three diets supplying similar energy, but having increased level of dietary CP content, i.e., $12.7 \%$, $14.7 \%$, and $16.6 \%$ of DM. The MP supply from these diets were 1992, 2264, and $2501 \mathrm{~g} / \mathrm{d}$, respectively. Weiss and Wyatt [35] estimated the MP supply from diets having two levels of CP content (Low CP and High CP) as per NRC [9]. They used two types of diet, one with Brown midrib (BMR) hybrid corn silage and the other with a dual purpose (DP) hybrid corn silage. The MP supply from low CP (14.4\%) and high CP (17.2\%) diets having BMR silage were 2350 and $3000 \mathrm{~g} / \mathrm{d}$, while the MP supply from low CP (14.2\%) and high CP (17.1\%) diets having DP silage were 2370 and $2970 \mathrm{~g} / \mathrm{d}$. The availability of MP in Chinese Holstein cows was evaluated at four levels of dietary CP, i.e., 11.9, 13.0, 14.2, and 15.4\% of DM [36]. The MP availability was $1.75,1.91,2.09$, and $2.16 \mathrm{~kg} / \mathrm{d}$ with corresponding MP level of 8.3, 8.9, 9.7, and $10.4 \%$ of DM. Das [22] evaluated the MP content of three TMRs having dietary CP content of $13.5,15$, and $16.5 \%$ of $\mathrm{DM}$ as $7.94,8.69$, and $9.28 \%$ of $\mathrm{DM}$, respectively, using CNCP system [30]. All these studies showed that there was a linear increase in MP availability from diets with an increased level of CP.

Yu et al. [37] compared availability of MP from three oat grain varieties such as CDC Dancer, Derby, and CDC SO-I (Super Oat) using NRC [9] model. The CP content of these varieties was $11.82,11.10$, and $12.81 \%$ of DM, while the MP content of these varieties was estimated at $7.43,7.16$, and $8.13 \%$ of
DM, respectively. Taghizadeh et al. [38] used in situ method to determine MP of 10 test feeds such as corn grain (CG), cottonseed meal (CSM), barley grain (BG), alfalfa hay-three cuts (AH), beet pulp (BP), tomato pomace (TP), lupin byproducts (LBP), and fish meal (FM). MP content of CG, CSM, BG, first cut $\mathrm{AH}$, second cut $\mathrm{AH}$, third cut $\mathrm{AH}, \mathrm{BP}, \mathrm{TP}, \mathrm{LBP}$ and FM was 3.5098, 23.2197, 4.8509, 6.6067, 6.3770, $4.8044,6.3005,16.3847$, and $39.6774 \mathrm{~g} / \mathrm{kg} \mathrm{DM}$. Vermeulen [27] calculated MP availability from range forage winter having $4 \% \mathrm{CP}$ and $49 \%$ TDN to be $81 \mathrm{~g} / \mathrm{d}$ when intake was about $2.2 \%$ of BW. MP supply from a high protein (HP) supplement $(41 \% \mathrm{CP})$ when fed at the rate of $1.36 \mathrm{~kg} / \mathrm{cow} /$ day was $158 \mathrm{~g} / \mathrm{d}$. Microbial MP availability was calculated to be $345 \mathrm{~g} / \mathrm{d}$.

Several research works used the Dutch MP system to predict the MP availability from different feeds. Yu and Racz [39] compared the DVE/OEB system with NRC [9] model in predicting MP supply from normal and frost damaged wheat. The MP content $(\mathrm{g} / \mathrm{kg} \mathrm{DM})$ of normal wheat was estimated to be 110.3 and 108.1, respectively, by the two models. Corresponding value for frost damaged wheat was 89.1 and $95.3 \mathrm{~g} / \mathrm{kg}$ DM. In a similar experiment [40], four varieties of hull-less barley (normal starch, zero amylase waxy, waxy, and high amylase) were found to have less MP content $(93.1,111.7,96.3$, and $87.4 \mathrm{~g} / \mathrm{kg} \mathrm{DM}$ ) as predicted by NRC [9] when compared to the DVE/OEB system $(116.5,122.9$, 113.5, and $102.9 \mathrm{~g} / \mathrm{kg} \mathrm{DM})$. Similarly, the MP value of carinata meal (Brassica carinata) was estimated as $153 \mathrm{~g} / \mathrm{kg}$ DM using the Dutch MP system [41]. The three major MP systems (PDI, DVE/OEB, and NRC) were compared in predicting the MP content of canola meal (CM) (yellow-seeded and brown-seeded) and canola press cake [42]. Yellow-seeded CM had higher total MP predicted by all three models (DVE/OEB, 312 vs. 192 and $128 \mathrm{~g} / \mathrm{kg} \mathrm{DM}$; NRC, 287 vs 193 and $168 \mathrm{~g} / \mathrm{kg} \mathrm{DM}$; PDI, 264 vs 168 and $137 \mathrm{~g} / \mathrm{kg} \mathrm{DM}$, respectively). Co-products from bioethanol processing units were evaluated for their MP content both by DVE/OEB and NRC systems, and it was found that the two models were highly correlated in predicting the MP values [43]. The MP contents of variously processed rice bran (RB), puffed RB, solvent extracted $\mathrm{RB}$ and expeller RB were estimated as $88,87,112$, and $128 \mathrm{~g} / \mathrm{kg} \mathrm{DM}$, respectively, by NRC model, while the corresponding values by DVE/OEB were 100, 105,118 , and $126 \mathrm{~g} / \mathrm{kg} \mathrm{DM}$, respectively [44].

Pooponpan et al. [45] estimated MP value of Wolffia meal in 3 weeks old broilers and found that the MP value of Wolffia meal in broiler was $34.46 \%$ of protein intake. Islam et al. [46] determined MP content of whole crop rice (WCR) silage for dairy cows. The estimated value of WCR silage (CP-8.21\%) was $4.29 \%$ of DM. They also found out that the stage of maturity of WCR was positively correlated with MP content and MP yield. Chase [47] evaluated MP availability from six commercial dairy herd rations. 
Rations with $14.3,15.9,15.7,15.8,15.5$, and $16.2 \%$ dietary CP supplied 2600, 3322, 2710, 2744, 2720, and $2779 \mathrm{~g} / \mathrm{d}$ of MP to dairy cows yielding between 35 and $50 \mathrm{~kg}$ milk/d, respectively. The corresponding MP (\% DM) content of the dairy rations was $10.5,12.2,11.1$, 11.2, 11.1, and 12.1, respectively. The MP content of grass pea (Lathyrus sativus L.) hay was estimated to be $534.7 \mathrm{~g} / \mathrm{kg} \mathrm{CP}$ in sheep [48]. In a similar study [49], the MP value of sainfoin (Onobrychis viciifolia) hay was evaluated as $483.4 \mathrm{~g} / \mathrm{kg} \mathrm{CP}$ in sheep. Treated and untreated pomegranate pomace contained 73 and $64.27 \mathrm{~g} \mathrm{MP} / \mathrm{kg}$ DM as per another study [50]. The MP content of Alhagi plant, a weed growing in areas of the hot climate and low rainfall was evaluated by Piri et al. [51] as $94.88 \mathrm{~g} / \mathrm{kg} \mathrm{DM}$. CM, treated canola meal, soybean meal (SBM), and the mixture of SBM and fish meal contained MP of $92,90,95$, and $96 \mathrm{~g} / \mathrm{kg} \mathrm{DM}$ as estimated by Huhtanen et al. [52].

Lee et al. [53] assigned randomly one of the following three diets to 36 cows; a diet with adequate MP balance $(+44 \mathrm{~g} / \mathrm{d})$ and $16.7 \% \mathrm{CP}$ concentration (AMP); a diet deficient in MP $(-156 \mathrm{~g} / \mathrm{d})$ and $14.8 \%$ CP concentration (DMP) or DMP supplemented with approximately $500 \mathrm{~g}$ coconut oil/head/d (DMPCO; $14.7 \% \mathrm{CP}$ concentration). The MP balance of these three diets according to NRC [9] was 44, -156 and $-288 \mathrm{~g} / \mathrm{d}$, respectively. Rahbarpour et al. [54] calculated MP value of untreated TP $(22.43 \% \mathrm{CP})$ as $19.04 \%$. When TP was treated with $1 \%$ and $2 \%$ urea level, the MP value increased to 20.82 and $21.50 \%$, respectively. Das et al. [55] evaluated the MP content of nine tropical ruminant feeds using in situ method. The MP contents ( $\mathrm{g} / \mathrm{kg} \mathrm{DM})$ of maize grain, groundnut cake, mustard oilcake, cotton seed cake, deoiled $\mathrm{RB}$, wheat bran, berseem fodder, maize fodder, and sorghum fodder were 95.26, 156.41, 135.21, 125.06, $101.68,107.11,136.81$, and 76.65 , respectively. They also arrived at the fact that the MP content of the feed is not constant as that of its $\mathrm{CP}$ content as it entirely depends on the protein degradation characteristics in an animal.

\section{Effect of MP supply on animal performances}

Cooper et al. [56] evaluated the effect of phase feeding of MP in 150 crossbred steer calves and found that phase feeding of MP could reduce $\mathrm{N}$ excretion while maintaining equal performance in terms of DM intake, daily gain, and feed efficiency between various treatment groups. Colin-Schoellen et al. [57] evaluated the effects of three levels of MP supply (protein digested in small intestine, when ruminal fermentable energy [PDIE] is limiting) in TMRs on milk production and composition in dairy cows. DM intake, net energy (NE) intake, and milk yield were significantly higher with increasing PDIE level. However, PDIE level of the diet did not affect the milk true protein content. Fat content decreased between low and medium PDIE levels and did not vary between medium and high PDIE level. Milk non protein N and milk urea N
(MUN) contents increased with an increased level of PDIE.

Whitlock et al. [58] fed increased dietary protein diet as TMR to prepubertal Holstein heifers (average BW $134 \mathrm{~kg}$ ) to see the effect on mammary development. The three experimental diets provided similar energy, i.e., $2.85 \mathrm{Mcal} / \mathrm{kg} \mathrm{DM}$ of $\mathrm{ME}$, but differed in their protein content, i.e., low protein, $13.7 \% \mathrm{CP}$, standard protein, $16.2 \% \mathrm{CP}$, and high protein, $18.8 \%$ protein. These diets supplied MP of 10.6, 11.6, and $12.65 \%$ of DM, respectively. Mammary development was higher with increasing dietary MP level. Blouin et al. [31] studied the effect of two isoenergetic (1.62 Mcal NE/kg DM) and isonitrogenous $(16.3 \% \mathrm{CP}$ of DM) diets supplying high $(1930 \mathrm{~g} / \mathrm{d})$ or low $(1654 \mathrm{~g} / \mathrm{d})$ MP in six catheterized late lactation Holstein cows. They observed that milk production was greater for high MP diet. Percentage of fat and percentage of protein tended to increase with low MP diet, while lactose concentration tended to increase with high MP diet. But total yield of fat, protein, and lactose was greater in case of high MP diet. Faverdin et al. [59] assessed the efficiency of MP supply in stimulation of food intake in lactating dairy cows. Two infusions of soya protein isolate $(800 \mathrm{~g} / \mathrm{d})$ were given either into the rumen-(RP) or the duodenum (DP). These infusions were compared with two isoenergy infusions of glucose $(880 \mathrm{~g} / \mathrm{d})$ either into the rumen (RG) or the duodenum (DG). These diets, i.e., RG, RP, DG, and DP supplied 1650, 1683, 1591, and $2255 \mathrm{~g} / \mathrm{d} \mathrm{MP}$, respectively. Duodenal infusions of protein (DP) significantly increased DMI, rate of intake, milk yield, protein content, and protein yield compared to the glucose infusions in the duodenum (DG). No significant effect was observed with RP compared to RG. However, the protein infusions had no effect on apparent digestibility of DM, OM, neutral detergent fiber, or acid detergent fiber and very small effects on ruminant fermentation variables. Hence, it was concluded that direct supply of MP stimulated DMI independently of ruminal digestion effects.

Patterson et al. [60] compared the responses of supplementing pregnant yearling heifers $(358 \mathrm{~kg} \mathrm{BW})$ to meet MPRs versus conventional CP supplementation (CPR) over 2-year period. The heifers grazed upland range and meadow hay. Increasing amount of meadow hay was fed during the last trimester. There were no differences in BW or body condition score (BCS) among treatment groups, but MPR cows were heavier $(425 \mathrm{~kg})$ than CPR cows (421 kg). Pregnancy rate as higher in MPR (91\%) compared to CPR treatment $(86 \%)$. However, there was no increase in calf weaning weight among various treatment groups. Raggio et al. [34] studied the effect of three levels of MP supply on milk production and composition in six catheterized multiparous lactating Holstein cows. Milk production increased linearly with increasing supply of MP. Milk CP yield and yield of each milk protein fraction increased linearly with increased MP 
supply. Milk CP concentration increased linearly, but the proportion of true protein decreased. Milk fat concentration decreased linearly resulting in a decrease in fat yield at the highest MP level.

Waterman et al. [61] studied the effect of three supplements that contained increasing amount of MP on post-partum interval and nutrient partitioning in 2-year-old young beef cows. Supplement 1 supplied required amount of MP according to NRC [9]; while supplement 2 provided $31 \mathrm{~g}$ excess MP and supplement 3 with $11 \%$ of calcium propionate supplied $36 \mathrm{~g}$ excess MP. As MP of diet with or without propionate increased, a decrease was observed in post-partum interval; but there was no influence on pregnancy $\%$ by the treatments. BCS was slightly improved on supplementation of $31 \mathrm{~g}$ of excess MP, and there was increased weaning weight of calves. Weiss and Wyatt [35] evaluated the effect of supply of low or high MP from both BMR hybrid corn silage and DP hybrid corn silage based diets on milk production in Holstein cows. It was observed that milk yield $(\mathrm{kg} / \mathrm{d})$, energy corrected milk yield $(\mathrm{kg} / \mathrm{d})$, milk fat $\%$, and milk fat yield $(\mathrm{kg} / \mathrm{d})$ were higher in high MP supply from both types of silage based diets. Milk protein percentage and milk protein yield $(\mathrm{kg} / \mathrm{d})$ were similar in both low and high MP supply from DP silage-based diet, while these parameters increased in high MP supply from BMR silage-based diet. Wang et al. [36] studied the effect of four levels of MP on milk production and $\mathrm{N}$ utilization in 40 Chinese Holstein dairy cows. The animals were offered with different levels of MP: 8.3, $8.9,9.7$, and $10.4 \%$ of DM. The study revealed that milk yield and milk protein percentage increased as the MP increased up to $9.7 \%$ of DM and then leveled off. Hence, It was concluded that the optimal dietary MP level was at $9.7 \%$ of DM for Chinese Holstein dairy cows producing $30 \mathrm{~kg}$ of milk/d.

Huhtanen et al. [62] carried out meta-analysis to evaluate the effect of silage soluble $\mathrm{N}$ components on MP concentration. The analysis showed that increased silage $\mathrm{N}$ solubility was associated with reduced milk protein yield and efficiency of $\mathrm{N}$ utilization and increased MUN concentration. Proportion of soluble non ammonia $\mathrm{N}$ in silage $\mathrm{N}$ had no effect on MP yield and consequently on the true silage concentration. Voltolini et al. [63] evaluated the effects of increasing MP supply beyond NRC [9] recommendations for mid lactating dairy cows grazing elephant grass pasture. Milk production, 3.5\% fat corrected milk (FCM), milk fat, protein, lactose, and total solids contents were not affected by treatments. Milk urea $\mathrm{N}$ and plasma urea $\mathrm{N}$ increased linearly as MP supply increased. Treatments also did not affect BW gain and BCS of animals, which indicated that the NRC [9] recommendations were adequate for mid lactating cows grazing tropical pastures. Weiss et al. [64] observed that on increasing the concentration of MP in the diet increased the digestibility of N. At low MP, the diet digestible energy concentration reduced but at high
MP, it increased. Increasing MP also increased energy correlated milk yield and protein.

Nichols et al. [65] evaluated the effect of feeding two levels of MP beyond NRC [3] recommendations in gestating 2-years-old heifers. Animals were subjected to two types of dietary treatments; one supplying $102 \%$ and the other supplying $119 \%$ of MPRs. Level of MP had no effect on calf birth weight, ADG, age at weaning, cow BW at calving, and proportion of cows returning to conceive. Hence, feeding excess MP during mid to late gestation did not enhance heifer productivity. Rius et al. [16] studied the interaction of energy and predicted MP in determining $\mathrm{N}$ efficiency in lactating dairy cows and found a high correlation between the two factors. Similar results were observed in sheep by Amaral et al. [66]. Imaizumi et al. [67] who observed that diets with same CP content did not supply the same MP amount to the animals. The efficiency of three types of diets on performances of 42 lactating Holstein cows was evaluated. The control diet $(16 \% \mathrm{CP}$ and $10.8 \% \mathrm{MP})$ supplied adequate MP according to NRC [9]. The two test diets were having more protein $(17.5 \% \mathrm{CP})$ by providing either extra SBM and cotton seed meal (SBCS-17.5) or extra urea (U-17.5). The MP supplied from these diets was 11.8 and $10.8 \%$, respectively. Milk and 3.5\% FCM yields were increased with SBCS-17.5 diet, but not by U-17.5 diet. Milk fat content and yield were not affected by treatments. Higher milk protein yields were observed for SBCS-17.5 treatment, but it decreased when fed U-17.5 diet. Emon et al. [68] evaluated the effect of gestational MP supplementation during last 50 days of gestation on ewe and lamb performances and suggested that ewes fed at $60 \%$ of MPRs as per NRC [69] could still maintain pregnancy without any negative effect on performance and carcass characteristics.

\section{Conclusion}

From the above discussions, it is clear that the dairy cow has two sets of $\mathrm{N}$ requirements: The $\mathrm{N}$ requirements of rumen microbes for optimum fermentation and the amino acids requirements of the cow. Considerable progress has been made in meeting these requirements with more accuracy. It should be made sure that the cow's RDP requirement is met so that rumen microbes get enough amino acids and ammonia for their growth. A deficiency will suppress the growth and activity of the microbes, decrease feed intake, and decrease the efficiency of MCP. However, excessive amounts of RDP feeding should also be avoided as it decreases the efficiency of use of dietary protein for milk protein production. Overfeeding of RUP is also not desirable as it lowers the efficiency of use of MP for milk protein production. The MP feeding standards for lactating cows represents a balance between animal requirements for MP and their fulfillment by dietary sources. The dairy cattle diets should preferably include a mixture of forages, processed grains, and agro-industrial byproducts in order to 
provide a suitable ratio of fermentable carbohydrate and dietary fiber for maximization of feed intake, milk yield, and MP yield. Many research works have reported improved herd health, reproduction and profitability when diets were balanced with MP. Despite some drawbacks, the MP system has merit in predicting and meeting the protein requirements of dairy cattle. The use of MP system should allow producers, researchers, and nutritionists to more accurately predict the type and amount of supplements necessary to achieve and maintain predetermined performance standards. By feeding the animals with correct amount specific diet at a specific time, the cost of production could also be significantly reduced. Thus, balancing the protein diet of dairy animals in terms of RDP, RUP, and MP is the best possible way for efficient utilization of nutrients and for maximizing milk production.

\section{Author's Contributions}

LKD collected and interpreted published informations on MP systems as part of his M.V.Sc thesis work. The manuscript was jointly prepared by LKD and DK. SSK and CD as principal and co-guide of LKD during his M.V.Sc programme at NDRI (2010-12) incorporated valuable suggestions for improvement of the manuscript. All authors read and approved the final manuscript.

\section{Competing I nterests} interests.

The authors declare that they have no competing

\section{References}

1. Datta, D. (2013). Indian fodder management towards 2030: A case of vision or myopia. Int. J. Manage. Soc. Sci. Res., 2(2): 33-41.

2. Dikshit, A.K. and Birthal, P.S. (2010). India's livestock feed demand: Estimates and projections. Agric. Econ. Res. Rev., 23: $15-28$

3. NRC. (1996). Nutrient Requirements of Beef Cattle. $7^{\text {th }}$ ed. National Academy Press, Washington, DC.

4. Van Soest, P.J. (1994). Nutritional Ecology of the Ruminant. $2^{\text {nd }}$ ed. Cornell University Press, Ithaca, New York.

5. Varga, G.A. (2007). Why use metabolizable protein for ration balancing? Proceedings of Pennsylvania State Dairy Cattle Nutrition Workshop, Grantville, PA. p. 51-57.

6. Beever, D.E. and Cottrill, B.R. (1994). Protein systems for feeding ruminant livestock: A European assessment. J. Dairy Sci., 77(7): 2031-2043.

7. Beever, D.E. (1996). Meeting the protein requirement of ruminant livestock. S. Afr. J. Anim. Sci., 26(1): 20-26.

8. Schwab, C.G. and Ordway, R.S. (2004). Balancing diets for amino acids: Implications of production efficiency and feed costs. Proceedings of Pennsylvania State Dairy Cattle Nutrition Workshop, Grantville, PA. p1-16.

9. NRC. (2001). Nutrient Requirements of Dairy Cattle. $7^{\text {th }}$ Revised ed. National Academy Press, Washington, DC.

10. Burroughs, W., Trenkle, A. and Vetter, R.L. (1974). A system of protein evaluation for cattle and sheep involving metabolizable protein (amino acids) and urea fermentation potential of feedstuffs. Vet. Med. Small Anim. Clin., 69(6): 713.

11. ARC. (1984). The Nutrient Requirements of Ruminant Livestock. Suppl. 1. Commonwealth Agricultural Bureaux, Slough, UK.
12. NRC. (1985). Ruminant Nitrogen Usage. National Academy Press, Washington, DC

13. AFRC. (1992). Technical Committee on Responses to Nutrients, Report No. 9. Nutritive Requirements of Ruminant Animals: Protein. Commonwealth Agricultural Bureaux, Slough, UK.

14. Kebreab, E., France, J., Mills, J.A.N., Allison, R. and Dijkstra, J. (2002). A dynamic model of $\mathrm{N}$ metabolism in the lactating dairy cow and an assessment of impact of $\mathrm{N}$ excretion on the environment. J. Anim. Sci., 80: 248-259.

15. Whitehouse, N., Schwab, C., Luchini, D., Tylutki, T and Sloan, B. (2009). Comparison of optimal lysine and methionine concentrations in metabolizable protein estimated by the NRC (2001), CPM-Dairy (v.3.0.10) and ATMS. Cattle (v.2.1.1) models. J. Anim. Sci., 92 (Suppl. 1): 103. (Abstr.)

16. Rius, A.G., Mcgilliard, M.L., Umberger, C.A. and Hanigan, M.D. (2010). Interactions of energy and predicted metabolizable protein in determining nitrogen efficiency in the lactating dairy cows. J. Dairy Sci., 93(5): 2034-2043.

17. Aboozar, M. (2012). Impacts of dietary metabolizable protein on performance and ruminal parameters of Holstein cows at early lactation. Res. Opin. Anim. Vet. Sci., 2(2): 102-108.

18. Lee, C., Hristov, A.N., Heyler, K.S. and Cassidy, T.W. (2012) Effect of metabolizable protein supply and amino acid supplementation on nitrogen utilization, milk production, and ammonia emission from manure in dairy cows. J. Dairy Sci., 95(9): 5253-5268.

19. Wilkerson, A., Klopfenstein, T.J., Britton, R.A., Stock, R.A. and Miller, P.S. (1993) Metabolizable protein and amino acid requirements of growing cattle. J. Anim. Sci., 71(10): 2777-2784

20. Verite, R. (1987). In: Jarrige, R. and Alderman, G., editors. Present situation of protein evaluation for ruminants in France: The PDI system. Commission of the European Communities, Luxembourg. p. 11-20.

21. Jarrige, R. (1989). Ruminant Nutrition: Recommended Allowances and Feed Tables. John Libbey Eurotext, Montrouge, France.

22. Das, L.K. (2012). Metabolizable protein availability from different feeds and the effects of its graded levels in the diet on nutrient utilization in growing Sahiwal calves. M.V.Sc. Thesis, Division of Dairy Cattle Nutrition, National Dairy Research Institute, Karnal, Haryana, India.

23. Robson, G.L.V., Filho, S.C.V., Diniz, R.V.F., Luciana, N.R., Veiga, P.P.R. and de Souza, M.A. (2007) Effects of increasing dietary crude protein levels on nitrogen balance and metabolizable protein requirements for maintenance in Nellore cattle. Braz. J. Anim. Sci., 36(4): 1212-1217.

24. Ezekiel, J.M.B. (1987). Protein and energy requirements of cattle: Endogenous fractions. Ph. D. Thesis in Animal Science. Federal University of Vicosa, Minas Gerais.

25. Valadares, R.F.D. (1997). Protein levels in diets for cattle: Intake, digestibility, microbial efficiency, ruminal ammonia, urea and plasma urea and creatinine excretions. $\mathrm{Ph}$. D. Thesis in Animal Science. Federal University of Vicosa, Minas Gerais.

26. Hill, M.M. (1998). Consumption, total and partial digestibility of diets containing different levels of concentrate in Nellore. M.Sc. Dissertation (Zoology), Federal University of Vicosa, Minas Gerais.

27. Vermeulen, C. (2001). Metabolizable protein requirements of early lactating beef cows grazing dormant native (Oklahoma) range. Agricola., 1:116-123.

28. Luo, J., Goetsch, A.L., Nsahlai, I.V., Sahlu, T., Ferrell, C.L., Owens, F.N., Galyean, M.L., Moore, J.E. and Johnson, Z.B. (2004a). Metabolizable protein requirements for maintenance and gain of growing goats. Small Rumin. Res., 53: 309-326.

29. Luo, J., Goetsch, A.L., Nsahlai, I.V., Sahlu, T., Ferrell, C.L., Owens, F.N., Galyean, M.L., Moore, J.E. and Johnson, Z.B. (2004b). Prediction of metabolizable energy and protein 
requirements for maintenance, gain and fiber growth of Angora goats. Small Rumin. Res., 53: 339-356.

30. Silva, A.M.A., Sobrinho, A.G.S., Trindade, I.A.C.M., Resende, K.T. and Bakke, O.A. (2007). Net and metabolizable protein requirements for body weight gain in hair and wool lambs. Small Rumin. Res., 67: 192-198.

31. CNCP. (2003). The net carbohydrate and protein system for evaluating herd nutrition and nutrient excretion. CNCPS Version 5.0., Cornell University, 130 Morrison Hall, Ethaca, New York.

32. Blouin, J.P., Bernier, J.F., Reynolds, C.K., Lobley, G.E., Dubreuilg, P. and Lapierre, H. (2002). Effect of supply of metabolizable protein on splanchnic fluxes of nutrients and hormones in lactating dairy cows. J. Dairy Sci., 85(10): 2618-2630.

33. Doepel, L. and Lapierre, H. (2006). Challenges in protein nutrition for dairy cows. WCDS Adv. Dairy Technol., 18: 57-67.

34. Raggio, G., Pacheco, D., Berthiaume, R., Lobley, G.E. and Pellerin, D. (2004). Effect of level of metabolizable protein on splanchnic flux of amino acids in lactating dairy cows. J. Dairy Sci., 87(10): 3461-3472.

35. Weiss, W.P. and Wyatt, D.J. (2006). Effect of corn silage hybrid and metabolizable protein supply on nitrogen metabolism of lactating dairy cows. J. Dairy Sci., 89(5): 1644-1653.

36. Wang, C., Liu, J.X., Yuan, Z.P., Wu, Y.M., Zhai, S.W. and Ye, H.W. (2007). Effect of level of metabolizable protein on milk production and nitrogen utilization in lactating dairy cows. J. Dairy Sci., 90(6): 2960-2965.

37. Yu, P., Rossnagel, B.G. and Niu, Z. (2008). Protein value of a new genotype oat (CDC SO-I) for the NRC dairy model: Protein degradation balance and kinetics, protein fractions and total metabolizable protein supply. Can. J. Anim. Sci., 88(3): 507-513.

38. Taghizadeh, A., Safamehr, A., Palangi, V. and Mehmannavaz, Y. (2008). The determination of metabolizable protein of some feedstuffs used in ruminants. Res. J. Biol. Sci., 3(7): 804-806.

39. Yu, P. and Racz, V. (2010). Modeling nutrient supply to ruminants: Frost damaged wheat vs. normal wheat. AsianAust. J. Anim. Sci., 23(3): 333-339.

40. Damiran, D. and Yu, P. (2012). Metabolic characteristics in ruminants of the protein in newly developed hull - less barley varieties with altered starch traits. J. Cereal Sci., 55: 351-360.

41. Xin, H. and Yu. P. (2014). Rumen degradation, intestinal and total digestion characteristics and metabolizable protein supply of carinata meal (a non-conventional feed resource) in comparison with canola meal. Anim. Feed Sci. Technol., 191: 106-110.

42. Theodoridou, K. and Yu, P. (2013). Metabolic characteristics of the proteins in yellow-seeded and brown-seeded canola meal and press cake in dairy cattle: Comparison of three systems (PDI, DVE and NRC) in nutrient supply and feed milk value (FMV). J. Agric. Food Chem., 61(11): 2820-2830.

43. Nuez Ortin, W. and Yu, P. (2010). Modeling the metabolic characteristics of proteins in dairy cattle from co-products of bioethanol processing: Comparison of the NRC 2001 model with DVE/OEB system. J. Sci. Food Agric., 91(3): 405-411.

44. Wang, Y., Xin, H.S., Li, Y.Z., Zhang, W.W., Xia, K., Wang, Z.B., Li, M. and Zhang, Y.G. (2012). The effects of different processing methods on the estimated nutritional value of rice bran according to NRC-2001 model or DVE/OEB system. J. Anim. Feed Sci., 21: 503-520.

45. Pooponpan, P., Chinrasri, O., Saenthaweesuk, S. and Chantiratikul, A. (2011). Evaluation of metabolizable protein and metabolizable energy values of Wolffia meal [Wolffia globosa (L). Wimm.] in broilers. Int. J. Poult. Sci., 10(5): 401-403.
46. Islam, M.R., Ishida, M., Ando, S., Nishida, T. and Yoshida, N. (2011). Whole crop rice silage: Prediction of yield and content of metabolizable energy, metabolizable protein and other nutrients for dairy cows from crop maturity and botanical fractions at harvest. Anim. Feed Sci. Technol., 163: 222-230.

47. Chase, L.E. (2011). Maintaning milk yield while lowering dietary protein content. WCDS Adv Dairy Technol., 23: 153-164.

48. Vahdani, N., Moravej, H., Rezayazdi, K. and DehghamBanadaki, M. (2014). Evaluation of nutritive value of grass pea hay in sheep nutrition and its palatability as compared with alfalfa. J. Agric. Sci. Techol., 16: 537-550.

49. Khalilvandi-Behroozyar, H., Dehghan-Banadaki, M. and Rezayazdi, K. (2010). Palatability, in situ and in vitro nutritive value of dried sainfoin (Onobrychis viciifolia). J. Agric. Sci., 148(6): 723-733.

50. Ebrahimi, B., Taghizadeh, A., Mehmannavaz, Y. and Palangi, V. (2012). Evaluation of pomegranate pomace using in situ and gas production techniques. J. Environ. Sci. Eng., A1: 951-955.

51. Piri, A., Palangi, V. and Eivazi, P. (2012). The determination of nutritive value of Alhagi by in situ and gas production techniques. Euro. J. Exp. Biol., 2(3): 846-849.

52. Huhtanen, P., Hetta, M. and Swensson, C. (2011). Evaluation of canola meal as a protein supplement for dairy cows: A review and a meta-analysis. Can. J. Anim. Sci., 91: 529-543.

53. Lee, C., Hristov, A.N., Heyler, K.S., Cassidy, T.W., Long, M., Corl, B.A. and Karnati, S.K.R. (2011). Effects of dietary protein concentration and coconut oil supplementation on nitrogen utilization and production in dairy cows. $J$. Dairy Sci., 94(11): 5544-5557.

54. Rahbarpour, A., Palangi, V., Eivagi, P. and Jalili, M. (2012). Calculation of metabolizable protein and energy of tomato pomace by nylon bags and gas production datas. Eur. $J$. Exp. Bio.,2(3): 822-825.

55. Das, L.K., Kundu, S.S., Kumar, D. and Datt, C. (2014). The evaluation of metabolizable protein content of some indigenous feedstuffs used in ruminant nutrition. Vet. World., 7(4): 257-261

56. Cooper, R., Milton, T. and Klopfenstein, T.J. (2000). Phase feeding of metabolizable protein in steers. Nebraska Beef Cattle Report. p62-65.

57. Colin-Schoellen, O., Jorjanz, S. and Laurent, F. (2000). Metabolizable protein supply (PDIE) and restricted level of ruminally degradable nitrogen (PDIN) in total mixed rations: Effect on milk production and composition and on nitrogen utilization by dairy cows. Livest. Prod. Sci., 67(1): 41-53.

58. Whitlock, B.K., Vandehaar, M.J., Silva, L.F.P. and Tucker, H.A. (2002). Effect of dietary protein on prepubertal mammary development in rapidly growing dairy heifers. J. Dairy Sci., 85(6): 1516-1525.

59. Faverdin, P., M'hamed, D. and Verite, R. (2003) Effects of metabolizable protein on intake and milk production of dairy cows independent of effects on ruminal digestion. Anim. Sci., 76: 137-146.

60. Patterson, H.H., Adams, D.C., Klopfenstein, T.J., Clark, R.T. and Teichert, B. (2003b) Supplementation to meet metabolizable protein requirements of primiparous beef heifers: II. Pregnancy and economics. J. Anim. Sci., 81(3): 563-570.

61. Waterman, R.C., Sawyer, J.E., Mathis, C.P., Hawkins, D.E., Donart, G.B. and Petersen, M.K. (2006). Effects of supplements that contain increasing amounts of metabolizable protein with or without Ca-propionate salt on postpartum interval and nutrient partitioning in young beef cows. J. Anim. Sci., 84(2): 433-446.

62. Huhtanen, P., Rinne, M. and Nousiainen, J. (2008). Effects of silage soluble nitrogen components on metabolizable protein concentration: A meta analysis dairy cow production experiments. J. Dairy Sci., 91(3): 1150-1158.

63. Voltolini, T.V., Santos, F.A.P., Martinez, J.C., Imaizumi, H., 
Pires, A.V. and Penati, M.A. (2008). Metabolizable protein supply according to the NRC (2001) for dairy cows grazing elephant grass. Sci. Agricola., 65(2): 130-138.

64. Weiss, W.P., St-Pierre, N.R. and Willett, L.B. (2009). Varying type of forage, concentration of metabolizable protein, and source of carbohydrate affects nutrient digestibility and production by dairy cows. J. Dairy Sci., 92(11): 5595-5606.

65. Nichols, B.M., Mcdonald, T.J., Harbac, M.M., Roberts, A.J. and Paterson, J.A. (2010). Effects of gestational dietary metabolizable protein level and dry matter intake on subsequent production traits in primiparous heifers. Proc. West. Sect. Am. Soc. Anim. Sci., 61: 35-40.

66. Amaral, G.A., Kozloski, G.V., Santos, A.B., Castagnino, D.S., Fluck, A.C., Farenzena, R., Alves, T.P. and Mesquita, F.R. (2011). Metabolizable protein and energy supply in lambs fed annual rye grass (Lolium multiflorum Lam.) supplemented with sources of protein and energy. J. Agric. Sci., 149(4): 519-527.

67. Imaizumi, H., Santos, F.A.P., Bittar, C.M.M., Correia, P.S. and Martinez, J.C. (2010). Diet crude protein content and sources for lactating dairy cows. Sci. Agricola., 67(1): 16-22.

68. Emon, M.L.V., Eckerman, S.E., Lekatz, L.A., Berg, P.B., Carlin, K.R.M., Vonnahme, K.A., Thompson, M.M. and Schauer, C.S. (2011). Effects of maternal metabolizable protein supplementation during the last 50 days of gestation on ewe and offspring performance and carcass characteristics. Sheep Research Report of USDA National Institute of Food and Agriculture. p17-22.

69. NRC. (2007). Nutrient Requirements of Small Ruminants. National Academy Press, Washington, DC.

$* * * * * * * *$ 